\title{
Potential and Viability of Stand Alone Solar PV Systems for Rural Electrification of Pakistan by using RET Screen Software
}

\author{
Tauseef Akbar $^{1}$, Dr. Amjad Ullah Gussan Maaz Mufti ${ }^{2}$ and Numan Khurshid ${ }^{1}$ \\ ${ }^{1}$ University of Engineering and Technology, Pakistan \\ ${ }^{2}$ National University of Sciences and Technology, Pakistan \\ 12gussanmufti@ces.nust.edu.pk
}

\begin{abstract}
Pakistan is facing energy crisis from last decade in spite having huge potential of solar energy. This research work will provide an assessment of the solar potential of Khyber Pakhtunkhwa (K.P.K) region. A comparison of the economic and financial analysis(Net Present Value, Internal Rate of Return, Payback period, and simple payback period) for a stand-alone PV systems for different regions of K.P.K have been done by simulating the solar systems on RET Screen. RET Screen has also been used for studying the effects of slope, latitude, orientation and geographical conditions of the selected six sites of K.P.K. Also, environmental effects such as Greenhouse gas (GHG) emission have been calculated and finally an optimum location for the installation of the solar panels has been proposed based on the results of the RET Screen.
\end{abstract}

Keywords: RET Screen, Photo voltaic system, Standalone system, Solar Energy, Payback period

\section{Introduction}

Energy is considered as the key element in the development of a country. The importance of energy in financial growth is recognized by the world and recent studies have established a direct relation between availability of energy and economic growth [1].According to International Energy Agency report, there would be 53\% increase in global primary energy consumption up to 2030 and $70 \%$ of this value is expected to come from developing nations [4].Currently, renewable energy contributes to only $11 \%$ of the world primary energy and this is expected to increase to $60 \%$ by 2070 [5].To counter these environmental and energy problems there is a need to explore cleaner and environmental friendly energy resources. Renewable energy resources can solve this problem to a substantial extent. Like other developing countries, Pakistan is also facing energy deficit of about $4 \mathrm{GW}$ inspire of the fact that Pakistan has huge potential of renewable energy resources [2].Pakistan's $60 \%$ of total foreign exchange is spent on importing fossil fuel for electric power generation. Due to shortage of electricity, industrial sector is adversely affected and Pakistan exports have reduced. Damage to Pakistan's economy is 2.5 billion \$/year due to the load shedding which is on an average $2 \%$ loss to country's GDP. In such circumstances, PV power generation would not only save the cost of importing fossil fuel but would also make up for the power shortage in the country hence, Pakistan's economy would grow (14).

Pakistan is the 6th most favorable country in the world in terms of solar irradiance and has a potential of about $2.9 \times 10^{3} \mathrm{GW}$ PV power generation capacity(13). This article is focused to analyze the implementation of solar photovoltaic for the domestic sector of Khyber Pakhtunkhwa (K.P.K) where blackouts of 6 to 7 hours are common. The annual direct solar radiation for K.P.K ranges between $3.9-5.1 \mathrm{KWh} / \mathrm{m}^{2} /$ day.Six major cities of K.P.K that is Peshawar, D. I. Khan, Mardan, Abbotabad, Dir and Chitral having different climatic and geographic conditions were being investigated. 


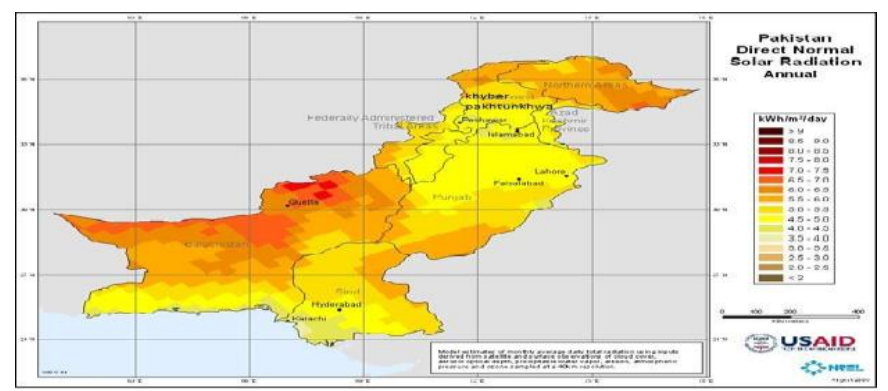

Figure 1. Pakistan Solar map [1]

RET Screen software is used to model 380 watts $(0.38 \mathrm{KW})$ stand-alone photovoltaic system for the above mentioned cities of K.P.K. The system is evaluated on the basis of economic determinants like Net Present Value, Internal Rate of Return, equity payback period and simple payback period for the determination of its viability. The effects of slope, latitude, orientation, weather conditions and geographical locations on the power generation of the selected sites of K.P.K is also being studied Financial analysis of the chosen sites is based upon the simulation done on the RET Screen. Finally, an optimum location for the installation of solar panels based upon the above mentioned limiting parameters is being proposed.

\section{Modeling of the System}

\subsection{Data Collection of Selected Sites}

Weather data holds importance while simulating the solar system. It is, therefore, essential that the weather data used is not only unquestionable, rather it is being verified by an authentic world agency. RET Screen uses the authentic weather data from NASA. The geographical locations and corresponding climatic conditions of the selected sites is shown in Figure.2 [9].Geological information of selected sites is mentioned in Table [I].

\subsection{Modeling of Stand-alone Photovoltaic System Components}

\subsubsection{Photovoltaic Array}

Evans [3] work is the base for the PV array models used in RET Screen software database, characterized by its efficiency $(\eta p)$, measured at a reference temperature $(\operatorname{Tr}=$ $25^{\circ} \mathrm{C}$ ) given by

$$
\eta \mathrm{p}=\eta \mathrm{r}[1-\beta(\mathrm{Tc}-\mathrm{Tr})]
$$

Where $\eta \mathrm{r}$ is nominal efficiency, $\beta$ is the temperature coefficient for module efficiency and Tc is the module temperature related to mean monthly ambient temperature Ta by Evans formula [3]

$$
\mathrm{T}_{\mathrm{c}}-\mathrm{T}_{\mathrm{a}}=\left(219+832 \mathrm{~K}_{\mathrm{t}}\right)[(\mathrm{NOCT}-20) / 800]
$$

Where $\mathrm{K}_{\mathrm{t}}$ is called clearance index and NOCT is the Normal Operating Cell Temperature.

The efficiency of the PV array in equation (1) is to be determined by two factors $\lambda \mathrm{p}$ and $\lambda \mathrm{c}$ and the power generated by array, Ea, is given by

$$
\mathrm{Ea}=\operatorname{Ht} p(1-\lambda \mathrm{p})(1-\lambda \mathrm{c})
$$




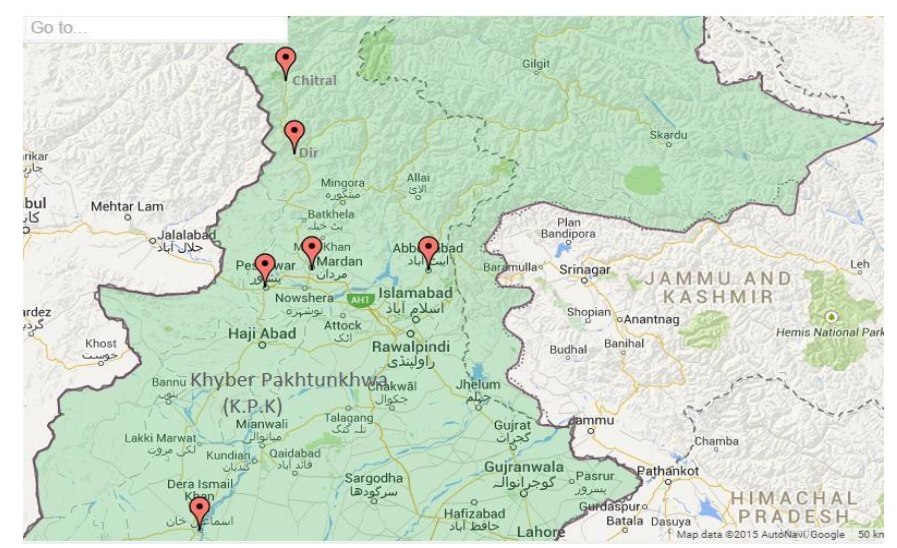

Figure 2. Stand-Alone PV Model Locations Selected for K.P.K [9]

Table 1. Climatic Features of Stand-Alone PV Model Sites in K.P.K

\begin{tabular}{|c|c|c|c|c|c|c|}
\hline \multirow{2}{*}{ Ambient data/ Climatic Location } & \multicolumn{4}{|c|}{ Climatic data } & \multirow{2}{*}{\multicolumn{2}{|c|}{ Chitral }} \\
\hline & Peshawar & Mardan & D. I. Khan & Abbottabad & & \\
\hline Latitude & $34.0^{\circ} \mathrm{N}$ & $34.2^{\circ} \mathrm{N}$ & $31.8^{\circ} \mathrm{N}$ & $34.2^{\circ} \mathrm{N}$ & $35.2^{\circ} \mathrm{N}$ & $36.0^{\circ} \mathrm{N}$ \\
\hline Longitude & $71.5^{\circ} \mathrm{E}$ & $72.0^{\circ} \mathrm{E}$ & $70.9^{\circ} \mathrm{E}$ & $73.2^{\circ} \mathrm{E}$ & $71.9^{\circ} \mathrm{E}$ & $71.8^{\circ} \mathrm{E}$ \\
\hline Air temperature (Annual) & $22.7^{\circ} \mathrm{C}$ & $14.3^{\circ} \mathrm{C}$ & $21.5^{\circ} \mathrm{C}$ & $10.3^{\circ} \mathrm{C}$ & $5.1^{\circ} \mathrm{C}$ & $-1.2^{\circ} \mathrm{C}$ \\
\hline Relative humidity (Annual) & $44.3 \%$ & $50.2 \%$ & $38.0 \%$ & $55.7 \%$ & $52.9 \%$ & $61.0 \%$ \\
\hline $\begin{array}{l}\text { Daily solar radiation horizontal } \\
\text { (Annual) }\end{array}$ & $\begin{array}{c}5.17 \\
\mathrm{kwh} / \mathrm{m}^{2} / \mathrm{d}\end{array}$ & $\begin{array}{r}5.31 \\
\mathrm{kwh} / \mathrm{m}^{2} / \mathrm{d}\end{array}$ & $4.86 \mathrm{kwh} / \mathrm{m}^{2} / \mathrm{d}$ & $\begin{array}{c}5.09 \\
\mathrm{kwh} / \mathrm{m}^{2} / \mathrm{d}\end{array}$ & $4.36 \mathrm{kwh} / \mathrm{m}^{2} / \mathrm{d}$ & $4.85 \mathrm{kwh} / \mathrm{m}^{2} / \mathrm{d}$ \\
\hline Atmospheric Pressure (Annual) & $96.7 \mathrm{kPa}$ & $82.9 \mathrm{kPa}$ & $92.5 \mathrm{kPa}$ & $77.8 \mathrm{kPa}$ & $72.0 \mathrm{kPa}$ & $66.6 \mathrm{kPa}$ \\
\hline Wind speed (Annual) & $5.0 \mathrm{~m} / \mathrm{s}$ & $5.2 \mathrm{~m} / \mathrm{s}$ & $4.1 \mathrm{~m} / \mathrm{s}$ & $5.0 \mathrm{~m} / \mathrm{s}$ & $5.2 \mathrm{~m} / \mathrm{s}$ & $5.4 \mathrm{~m} / \mathrm{s}$ \\
\hline $\begin{array}{c}\text { Heating } \\
\text { degree-days (Annual) }\end{array}$ & $555^{\circ} \mathrm{C} / \mathrm{d}$ & $1,953{ }^{\circ} \mathrm{C} / \mathrm{d}$ & $718{ }^{\circ} \mathrm{C} / \mathrm{d}$ & $2,918{ }^{\circ} \mathrm{C} / \mathrm{d}$ & $4,717^{\circ} \mathrm{C} / \mathrm{d}$ & $7,013{ }^{\circ} \mathrm{C} / \mathrm{d}$ \\
\hline $\begin{array}{c}\text { Cooling } \\
\text { degree-days (Annual) }\end{array}$ & $4,644^{\circ} \mathrm{C} / \mathrm{d}$ & $2,145^{\circ} \mathrm{C} / \mathrm{d}$ & $4,234{ }^{\circ} \mathrm{C} / \mathrm{d}$ & $1,279{ }^{\circ} \mathrm{C} / \mathrm{d}$ & $706{ }^{\circ} \mathrm{C} / \mathrm{d}$ & $113{ }^{\circ} \mathrm{C} / \mathrm{d}$ \\
\hline Earth temperature & $17.0^{\circ} \mathrm{C}$ & $16.1{ }^{\circ} \mathrm{C}$ & $24.7{ }^{\circ} \mathrm{C}$ & $11.7^{\circ} \mathrm{C}$ & $7.0^{\circ} \mathrm{C}$ & $0.4{ }^{\circ} \mathrm{C}$ \\
\hline
\end{tabular}

A mono-Si PV array model is used for the simulation purposes having characteristics given by Table II.

Table 2. Characteristics of the Selected PV Model

\begin{tabular}{|c|c|}
\hline Parameter & Value \\
\hline PV type & Mono-Si \\
\hline Module & Mono-Si-CSUN285-72M \\
\hline Manufacturer & $285 \mathrm{~W}$ \\
\hline Capacity & $14.7 \%$ \\
\hline Efficiency & 2 \\
\hline No. of units used & $45^{\circ} \mathrm{C}$ \\
\hline Nominal operating Temperature & $0.40 \% /{ }^{\circ} \mathrm{C}$ \\
\hline Temperature coefficient & $3.9 \mathrm{~m}^{2}$ \\
\hline Solar collector area & $1.0 \%$ \\
\hline Miscellaneous losses & \\
\hline
\end{tabular}


Table 3. Parameters of Charge Controller

\begin{tabular}{|c|c|}
\hline Model & Muse-2015LNS \\
\hline Battery input voltage & $12 / 24$ Vautomatic adaptation \\
\hline Charging current & $20 \mathrm{~A}$ \\
\hline Working temperature & $-25^{\circ} \mathrm{C}$ to $55^{\circ} \mathrm{C}$ \\
\hline Efficiency & $90 \%$ \\
\hline
\end{tabular}

Table 4. Specification of Inverter

\begin{tabular}{|c|c|}
\hline Model & MK-500PS-242 \\
\hline Output power & $500 \mathrm{~W}$ \\
\hline Waveform & Pure sine waveform \\
\hline DC Input voltage & $24 \mathrm{~V}$ \\
\hline Output voltage & $220 \mathrm{~V}$ \\
\hline Efficiency & $90 \%$ \\
\hline Protection functions & $\begin{array}{c}\text { Low/over voltage, Overload, } \\
\text { Overtemperature, Short circuit, Input reverse } \\
\text { connection }\end{array}$ \\
\hline
\end{tabular}

Table 5. Electrical Data of Battery

\begin{tabular}{|c|c|}
\hline Model & DB $12-350$ \\
\hline Nominal voltage & $12 \mathrm{~V}$ \\
\hline Nominal capacity & $350 \mathrm{Ah}$ \\
\hline Storage capacity & $8.4 \mathrm{kwh}$ \\
\hline
\end{tabular}

\section{RET Screen Software}

Total AC and DC load fed is converted to equivalent demand by the software algorithms [7]. The characteristic of the load for which stand-alone system is modeled is shown in Figure. 4.

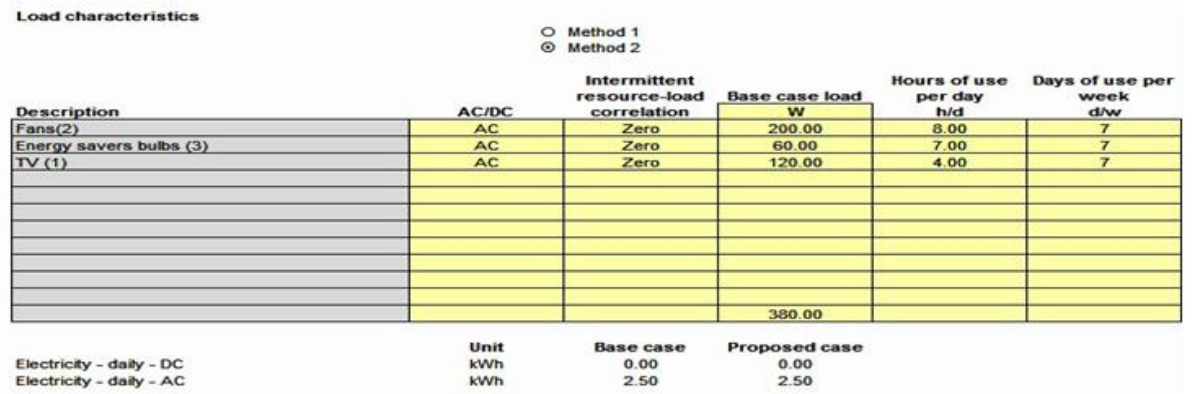

Figure 4. Load Characteristics

For continuous supply of power with two days autonomy, two batteries of lead-acid $12 \mathrm{~V}, 350 \mathrm{Ah}$ connected in series are used to provide back up during cloudy/rainy days with $80 \%$ depth of discharge. In such case study, financial aspects like fuel cost escalation rate, discount rate, and inflation rate are of vital importance in making a system feasible or not. In Pakistan, inflation rate is $6.08 \%$ [10], discount rate is reduced to $8 \%$ by state bank of Pakistan [11] and fuel cost escalation rate is $7.31 \%$ [10]. The basic inputs used in RET Screen software for Modeling stand-alone photovoltaic system for domestic consumers is listed in the Table [VI]. 
Table 6. Input Parameters

\begin{tabular}{|c|c|}
\hline Parameter & Value \\
\hline Battery voltage & $24 \mathrm{~V}$ \\
\hline Days of autonomy & 2.0 \\
\hline Maximum batterydepth of discharge & $80 \%$ \\
\hline Temperature control method & Ambient \\
\hline Solar tracking mode & Fixed \\
\hline Control method & MPPT \\
\hline PV panel cost & $130 \mathrm{PKR} / \mathrm{kw}$ \\
\hline Fuel cost escalation rate & $7.31 \%$ \\
\hline Discount rate & $8 \%$ \\
\hline Inflation rate & 6.08 \\
\hline
\end{tabular}

\section{Results}

The viability of the stand-alone photovoltaic system is being analyzed by considering technical, financial and environmental parameters. The results of the simulations are being discussed below.

\subsection{Technical Analysis}

The power delivered to the load is different for all the cities due to the difference in solar irradiance values. Hence it can be said that the output power is dependent on the solar irradiance value in the corresponding region. Results from the Table [VII] demonstrate that higher the solar irradiance value the greater is the power delivered to the load.

Table 7. Annual Daily Solar Radiation Horizontal and Power Delivered

\begin{tabular}{|c|c|c|}
\hline City name & $\begin{array}{c}\text { Annual daily Solar radiations } \\
\left(\mathbf{k w h} / \mathbf{m}^{2} / \mathbf{d}\right)\end{array}$ & $\begin{array}{c}\text { Power delivered } \\
(\mathbf{M W h})\end{array}$ \\
\hline Peshawar & 5.16 & 0.98 \\
\hline Abbottabad & 5.09 & 0.96 \\
\hline D.I.Khan & 4.86 & 0.93 \\
\hline Dir & 4.63 & 0.90 \\
\hline Mardan & 5.31 & 0.99 \\
\hline Chitral & 4.85 & 0.94 \\
\hline
\end{tabular}

\subsection{Financial Analysis}

Financial or economic performance of the project can be envisioned on the basis of economic determents like IRR, PV, equity and simple Payback periods. Economic investigation for the current case study is discussed below in detail.

\subsubsection{Net present Value (NPV) and Internal Rate of Return (IRR):}

Net Present Value and Internal Rate of Return have highest values for Mardan while least for Dir as shown in Table [VIII]. This elaborates the fact that the higher the value of daily horizontal solar radiations, greater would be the values of Net Present Value and Internal Rate of Return. 
Table 8. Trend of NPV and IRR

\begin{tabular}{|c|c|c|}
\hline City name & $\begin{array}{c}\text { Net Present Value (NPV in } \\
\text { PKR) }\end{array}$ & $\begin{array}{c}\text { Internal Rate of Return } \\
\text { (IRR in \%) }\end{array}$ \\
\hline Mardan & 169,533 & 19.7 \\
\hline Peshawar & 169,432 & 19.6 \\
\hline Abbottabad & 169,269 & 19.5 \\
\hline Chitral & 166,401 & 17.9 \\
\hline D .I. Khan & 169,433 & 19.4 \\
\hline Dir & 165,582 & 19.3 \\
\hline
\end{tabular}

5.2.2. Benefit Cost ratio (B-C): RET Screen calculates the net benefit-cost ratio, which is defined as the ratio of the net benefit to the cost of the project in consideration. If the ratio is greater than 1 , project is considered to be profiTable. For the current case study, benefit cost ratio of all cities are shown in Figure.

5.5.2.3. Payback period: Figure 6 displays the equity payback period and simple payback period for all the cities of case study, it illustrates that both periods are minimum for Mardan and maximum for Dir. From an economic point of view, payback period values for all cities are much smaller than suggested 25 years life of the project. The cash flow for Mardan having least payback period among the six cities. Considering the payback periods and cash flows of Mardan, it is evident that the cost of the project would be recovered aftersix years making it most feasible.

5.3. Emission Analysis: RET Screen emission analysis is used to find the net GHG emission reduction likely attribuTable to standalone PV system in carefully chosen locations of K.P.K. Results shows that each city leads to $1.4 \mathrm{tCO} 2$ emission reduction which is equivalent to 602 liters of gasoline that is being saved.

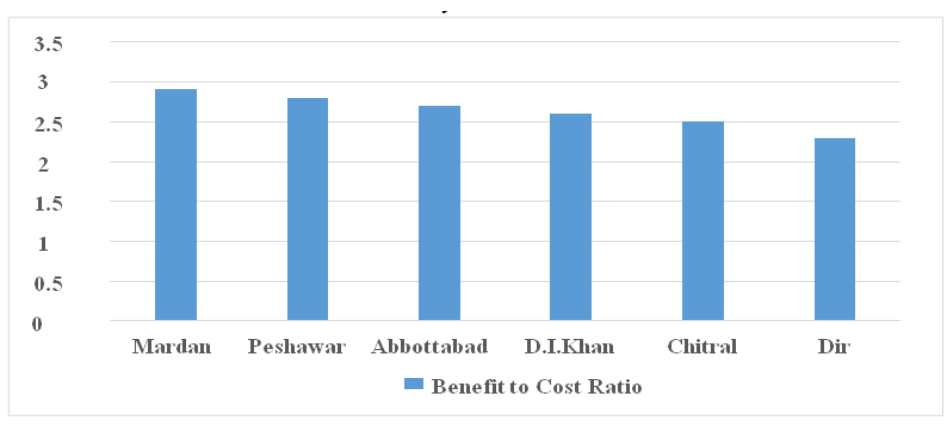

Figure. 5. Benefit Cost Ratio

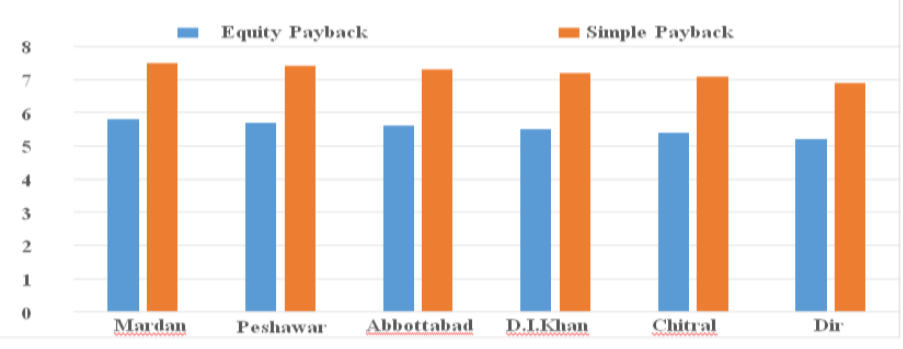

Figure 6. Payback Periods of Case Study 


\section{Conclusion}

A stand-alone PV system is evaluated by RET Screen software for six main cities of K.P.K. belonging to the different climatic conditions and geographical locations. Technoeconomic assessment of demonstrated system is done in terms of power delivered to the load, Net Present Value, Internal Rate of Return, Benefit to Cost Ratio, Simple and Equity Payback Periods and GHG emission reduction analysis. The results revealed that feasibility of stand-alone PV system for any region is dependent on the annual daily solar radiation value in that region. Higher the value of solar irradiance, greater is the PV potential and system would be economical. Analysis revealed that setting up a stand-alone PV system is feasible for all the six locations but Mardan is optimum and Dir is least suiTable. Hence, stand-alone PV technology is not only helpful in fulfilling the needs of the electricity of the domestic consumers but also ensuring the increase in the renewable energy growth of the region.

\section{References}

[1] A. Aqeel and M. S. Butt, "The relationship between energy consumption and economic growth in Pakistan,” Asia Pacific Dev. J., vol. 8, no. 2, pp. 101-109, 2001

[2] T. Muneer, S. Maubleu, and M. Asif, "Prospects of solar water heating for textile industry in Pakistan," Renew. Sustain. Energy Rev., vol. 10, no. 1, pp. 1-23, Feb. 2006

[3] D.L.Evans, "Simplified method for predicting photovoltaic array output," Sol. Energy, vol. 27, no. 6, pp. 555-560, 1981

[4] V. Applasamy, "Photovoltaic Power System in Malaysia," pp. 214-218, 2011

[5] E. Harder and G. J. MacDonald "The costs and benefits of large-scale solar photovoltaic power production in Abu Dhabi, United Arab Emirates", Renewable Energy, vol. 36, no. 2, (2011), pp. 789-96.

[6] D. Thevenard, “The Ret Screen Model For Assessing Potential Pv Projects”, Photovoltaic Specialists Conference, 2000, Conference Record of the Twenty-Eighth IEEE.

[7] D. Thevenard, G. Leng and S. Martel, "The RETScreen model for assessing potential PV projects", Conf. Rec, Twenty-Eighth IEEE Photovolt. Spec. Conf. - 2000 (Cat. No.00CH37036), (2000), pp. $1626-1629$,

[8] "RETScreen, Clean Energy Project Analysis", Tech. report, [Online] Available at: http://www.retscreen.net/ang/home.php, as at $20^{\text {th }}$ May'2010.

[9] “Zee-Maps." [Online]. Available: www.zeemaps.com

[10] G. of P. Statistics Division, Pakistan Bureau of Statistics, "Press Release on Inflation Rate," 2013.

[11] S. B. of Pakistan, "Monitory Policy Statement".

[12] R. A. Brealey and S. C. Myers, "Principles of corporate finance, 6th Edition", Irwin McGraw-Hill, (2008).

[13] G. M. Mufti et.al, "Optimization of Physical Dimensions for Efficient Parabolic Trough Collectors using Mathematical and Computational Models", International Conference on Modeling and Simulation 2013 (ICOMS 2013), Islamabad, Pakistan, (2013) November 25-27.

[14] M. F. Aziz and N. Abdulaziz, "Prospects and challenges of renewable energy in Pakistan", in Energy Conference and Exhibition (EnergyCon), 2010 IEEE International, (2010), p. 161-5. 
International Journal of Smart Home

Vol. 9, No. 8 (2015) 